\title{
PENGARUH PENDEKATAN BERMAIN TERHADAP OPTIMALISASI GERAK DASAR LARI ESTAFET PADA SISWA KELAS V DI SD NEGERI 2 LURAH KABUPATEN CIREBON
}

\author{
Riza Sukma Fauzi ${ }^{1}$ dan Nina Septiani ${ }^{2}$ \\ Universitas Majalengka, Indonesia \\ rizasukma@gmail.com
}

\begin{abstract}
ABSTRAK. Latar belakang dalam penelitian ini yaitu kurangnya ke aktifan gerak siswa dalam mengikuti pembelajaran penjas khusus nya atletik lari pada siswa kelas V SDN 2 Lurah. Identifikasi malasah dalam penelitian ini yaitu : 1 . Kurangnya keluasaan gerak pada siswa. 2. Kurangnya pengalaman gerak pada siswa. 3. Kurangnya pengembangan permainan oleh guru yang bisa menambah pengalaman gerak pada siswa terutama pada pembelajaran penjas. Rumusan masalah dalam penelitian ini yaitu: Bagaimana pengaruh pendekatan bermain terhadap optimalisasi gerak dasar lari estafet?" Tujuan penelitian ini yaitu : "Untuk mengetahui pengaruh pendekatan bermain terhadap optimalisasi gerak dasar lari estafet" Dalam penelitian ini peneliti menggunakan metode eksperimen. Populasi dalam penelitian ini adalah siswa kelas V SDN 2 Lurah. Pengambilan sampel dalam penelitian ini adalah Total Sampling. Penentuan sampel yang digunakan 35 orang dari 35 jumlah populasi. Berdasarkan hasil pengolahan data dan analisi data maka dapat disimpulkan bahwa diperoleh nilai $\mathrm{T}$ hitung 23.71 lebih besar dari $\mathrm{T}$ table 2.03224 . dengan demikian Ho ditolak Ha diterima. Itu berarti pendekatan bermain bembeerikan pengaruh yang positif dan signifikan terhadap hasil belajar optimalisasi gerak dasar lari estafet pada siswa kelas V SDN 2 Lurah. Dengan demikian hipotesis diterima.
\end{abstract}

Kata Kunci: Pendekatan Bermain; Gerak Dasar; Lari Estafet

\section{Pendahuluan}

Atletik secara terminologi adalah suatu bentuk kegiatan manusia sehari-hari yang diperlombakan dalam bentuk jalan, lari, lempar, dan lompat.Semua gerakan yang tidak terlepas dari kehidupan manusia, kegiatan yang digunakan sehari-hari. Menurut Muhajir (2007) "Atletik adalah olahraga yang tumbuh dan berkembang bersamaan dengan kegiatan alami manusia. Berlari, meloncat, dan melempar adalah bagian yang tak terpisahkan dari sejarah panjang kehidupan Indonesia”. Sedangkan menurut Sukirno, (2010) adalah olahraga yang paling tua dan merpakan induk dari semua cabang olahraga, oleh sebab itu atletik sering disebut sebagai the mother of sport'.

Lari sambung atau lari estafet adalah salah satu nomor lomba lari pada perlombaan atletik yang dilaksanakan secara bergantian atau berantai. Dalam satu regu lari sambung ada empat orang pelari, yaitu pelari pertama, kedua, ketiga, dan keempat. Pada masing-masing pelari start yang digunakan berdeda, pada pelari pertama menggunakan start jongkok dan pelari kedua, tiga, dan empat menggunakan start melayang. Pada start jongkok ada beberapa jenis yaitu start pendekatau bunch start, start menengah atau medium start, start panjang atau long start. Kemudian posisi tubuh pada saat berlari harus diperhatikan, posisi tubuh harus condong 
kedepan secara wajar dengan sedikit membusungkan dada, dan posisi badan pada saat mendekati garis finish baiknya pelari tidak memperpendek langkah kakinya dan menurunkan kekuatan ayunan tangannya.

Suksesnya lari estafet sangat bergantung dari kelincahan penggantian tongkat. Waktu yang dicapai akan lebih baik (lebih cepat) jika pergantian tongkat estafet berlangsung dengan baik pula. Suatu regu lari estafet yang terjadi dari pelari- pelari yang baik hanya akan dapat memenangkan perlombaan, jika mampu melakukan pergantian tongkat estafet dengan sukses.

Terkait permasalahan dalam pembelajaran gerak dasar lari di salah satu sekolah dasar yang terletak di Kabupaten Cirebon yaitu kurangnya koordinasi gerak dalam melakukan gerak dasar lari estafet. Sehingga siswa mengalami kesulitan pada saat melakukan fase-fase dalam gerak dasar lari estafet. Peneliti tertarik untuk memberikan solusi pembelajaran gerak dasar lari estafet menggunakan pendekatan bermain.

Menurut Ma'mun \& Subroto (2001) menyatakan bahwa : "pendekatan Bermain dalam permainan adalah untuk mening-katkan kesadaran siswa tentang konsep bermain melalui penerapan teknik yang tepat sesuai dengan masalah atau situasi dalam permainan sesungguhnya". Pendekatan bermain dalam pembelajaran Pendidikan Jasmani Olahraga dan Kesehatan pada pokok bahasan gerak dasar lari estafet, memberikan kelebihan dan manfaat yang baik bagi peserta didik.

\section{Metode Penelitian}

Metode yang digunakan menggunakan metode ekperimen dengan desain penelitian desain one group pretest-posttest. penelitian yang dilakukan menurut desain one group pretest-posttest adalah diberikannya pretest $(\mathrm{O} 1)$, dalam penelitian ini tes yang diberikan pada subjek penilaian adalah pengenalan gerak dasar lari estafet untuk mengetahui tingkat keterampilan gerak dasar lari estafet subjek penelitian. Setelah diberikan pretest maka subjek penelitian diberikan perlakuan (X), dalam penelitian ini perlakuan yang diberikan adalah pendekatan bermain Setelah diberikan perlakuan dalam beberapa pertemuan, maka subjek penelitian diberikan posttest $(\mathrm{O} 2)$ yaitu tes lari estafet untuk mengetahui perubahan tingkat keterampilan gerak dasar lari estafet. Hasil dari perlakuan akan dilihat dengan posttest.

Populasi dan sampel yang digunakan yakni sdmua kelas atas kelas V yang berjuml Tes keterampilan gerak dasar lari estafet, Tes dan pengukuran dalam penelitian ini dilaksanakan untuk mendapatkan data tentang hasil lari estafet yang dilaksanakan dua kali yaitu pre-test dan post-test. Hasil tes dicatat dalam satuan centimeter. 


\section{Hasil dan Pembahasan}

Karena Hipotesis alternative (Ha) diterima dan Ho ditolak pada nilai signifikansi 0.05 dan 0.01, maka dapat disimpulkan bahwa nilai yang sebelum dilalukan perlakuan (pretest) dan sesudah dilakukan perlakuan (posttest) memiliki selisih sangat besar yaitu 33.2 yang dapat disimpulkan bahwa antusias anak dalam mengikuti pembelajaran penjas meningkat.

Analisis Pretest-PostTest

\begin{tabular}{|c|c|c|c|c|c|c|}
\hline & & & & $\begin{array}{c}d i \mathrm{xi}- \\
\mathrm{yi})\end{array}$ & 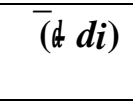 & $\overline{(}(\sharp d i)^{2}$ \\
\hline 1. & ABI PRASETIYO & 65 & 80 & -15 & 48,2 & 2323,24 \\
\hline 2. & ABIZAR AHMAD FIRDAUS & 25 & 60 & -35 & 68,2 & 4651,24 \\
\hline 3. & AHMAD ALIF FAKHRI & 90 & 92 & -2 & 35,2 & 1239,04 \\
\hline 4. & AHMAD FAUZI & 35 & 90 & -55 & 88,2 & 7779,24 \\
\hline 5. & AISYALUNA PUTRI S & 40 & 80 & -40 & 73,2 & 5358,24 \\
\hline 6. & AHMAD RIFAI & 60 & 95 & -35 & 68,2 & 4651,24 \\
\hline 7. & ALAN SIDIK & 25 & 80 & -55 & 88,2 & 7779,24 \\
\hline 8. & ANDRIYANSYAH & 30 & 80 & -50 & 83,2 & 6922,24 \\
\hline 9. & ARIF LUKMAN & 70 & 85 & -15 & 48,2 & 2323,24 \\
\hline 10. & ARIVA NURKHASANAH & 35 & 75 & -40 & 73,2 & 5358,24 \\
\hline 11. & ATIKA PUTRI RAMADHANI & 30 & 80 & -50 & 83,2 & 6922,24 \\
\hline 12. & AZIZAH & 45 & 80 & -35 & 68,2 & 4651,24 \\
\hline 13. & BAGUS & 65 & 80 & -15 & 48,2 & 2323,24 \\
\hline 14. & ELIN MELINDA & 35 & 90 & -55 & 88,2 & 7779,24 \\
\hline 15. & FADLY FADILLA & 25 & 80 & -55 & 88,2 & 7779,24 \\
\hline 16. & FITRI NURROHADATUL & 50 & 80 & -30 & 63,2 & 3994,24 \\
\hline 17. & HAFIZH AZHAR HIDAYAT & 45 & 80 & -35 & 68,2 & 4651,24 \\
\hline 18. & HAMIDAH & 70 & 85 & -15 & 48,2 & 2323,24 \\
\hline 19. & IBNU AIMADUDIN & 70 & 90 & -20 & 53,2 & 2830,24 \\
\hline 20. & IHWANSYAH & 30 & 80 & -50 & 83,2 & 6922,24 \\
\hline 21. & IKA RAHMAWATI & 80 & 95 & -15 & 48,2 & 2323,24 \\
\hline 22. & INAKA SINAR M. & 50 & 95 & -45 & 78,2 & 6115,24 \\
\hline 23. & INDRI JULIANTI & 20 & 75 & -55 & 88,2 & 7779,24 \\
\hline 24. & KINTAN NAURA CAHYANI & 50 & 75 & -25 & 58,2 & 3387,24 \\
\hline 25. & KIRANA PERTIWI & 50 & 65 & -15 & 48,2 & 2323,24 \\
\hline 26. & LIVRIYADI & 60 & 80 & -20 & 53,2 & 2830,24 \\
\hline 27. & MOHAMAD ARI SUGIARTO & 75 & 85 & -10 & 43,2 & 1866,24 \\
\hline 28. & MUHAMAD IHYA R & 55 & 95 & -40 & 73,2 & 5358,24 \\
\hline 29. & NABIL RAHMADANI & 65 & 85 & -20 & 53,2 & 2830,24 \\
\hline 30. & NADA ROHANI & 35 & 75 & -40 & 73,2 & 5358,24 \\
\hline 31. & NADHIATU NURRACHMAN & 25 & 75 & -50 & 83,2 & 6922,24 \\
\hline 32. & NIA AGUSTIN & 40 & 75 & -35 & 68,2 & 4651,24 \\
\hline 33. & NUR YANTIKA & 40 & 75 & -35 & 68,2 & 4651,24 \\
\hline 34. & NURMAYANTI & 75 & 85 & -10 & 43,2 & 1866,24 \\
\hline 35. & PUTRI AYU RAMADHANI & 50 & 95 & -45 & 78,2 & 6115,24 \\
\hline & Jumlah & 1710 & 2872 & -1162 & 2324 & 162939 \\
\hline & Rata-Rata & 48,857 & 82,057 & $-33,200$ & & \\
\hline
\end{tabular}


Catatan : Nilai makin besar maka tingkat arousal anak makin besar

Pada tabel didapatkan rata-rata perbedaan selisih $=-33.2$

\section{Kesimpulan}

Berdasarkan hasil analisis data yang telah dilakukan, maka diperoleh kesimpulan sebagai berikut: "Penggunaan metode pendekatan bermain cukup efektif dalam penerapan pembelajaran untuk meningkatkan keterampilan gerak dasar lari estafet pada siswa kelas $\mathrm{V}$ di SD Negeri 2 Lurah Kabupaten Cirebon”.

\section{Daftar Pustaka}

Badriah, D. L. (2012). Metodologi Penelitian Ilmu-ilmu Kesehatan. Bandung : Multazam. eprints.uny.ac.id

http://alisarjunip.blogspot.com/2014/06/dewfenisi-populasi-menurut- arikunto.html

https://eprints.uns.ac.id/1975/1/1579-3506-1-SM.pdf https://www.jatikom.com/2018/10/pengertianmacam-jenis-sejarah-atletik

gambar-penjelasan.html https://kickriza.wordpress.com/2011/05/14/pengertian-dari-gerak-dasar/ http://www.artikelsiana.com/2017/11/pengertian-atletik-sejarah-nomor.html Hendrayana Yudi. 2014. Bermain Atletik. Jakarta: Depdiknas dan Dirjen OR, 2001.

Kurikulum Tingkat Satuan Pendidikan Sekolah Dasar. Model Silabus dan RPP kelas V.

Rahyubi, H. (2014). Teori-Teori Belajar dan Aplikasi Pembelajaran Motorik. Majalengka. Nusa Media. Sidik, D. Z. (2014). Mengajar dan Melatih Atletik. Bandung: PT. Remaja Rosdakarya.

Sugiyono. (2018). Metode Penelitian Pendidikan Pendekatan Kuantitatif, Kualitatif, dan R\&D. Bandung : Alfabeta 